\title{
Squamous Odontogenic Tumor
}

National Cancer Institute

\section{Source}

National Cancer Institute. Squamous Odontogenic Tumor. NCI Thesaurus. Code C7112.

A rare, locally invasive neoplasm arising from tooth-forming tissues. It usually grows intraosseously in the mandible. The maxilla is less frequently involved. It is characterized by the presence of well differentiated squamous cells which form islands. Recurrences may rarely occur and probably are related to incomplete excision of the tumor. 